大学男子ラグビー選手のトレーニング量の差異と栄養素および食品群別摂取量の関連性 西村 貴子 ${ }^{1,2}$, 熊原 秀晃 ${ }^{3 \%}$, 後藤 亜里沙 ${ }^{3}$, 西嶋 彩 $^{3}$, 芳山ももこ ${ }^{3}$, 村上 純 $^{4}$, 大和 孝子 $^{3}$

\title{
Association between various levels of training-related energy expenditure and dietary and nutrient intake in Japanese male collegiate rugby players
}

\author{
Takako Nishimura $^{1,2}$, Hideaki Kumahara ${ }^{3 *}$, Arisa Goto ${ }^{3}$, Sayaka Nishijima ${ }^{3}$, \\ Momoko Yoshiyama ${ }^{3}$, Jun Murakami ${ }^{4}$ and Takako Yamato ${ }^{3}$ \\ ${ }^{1}$ 中村学園大学大学院栄養科学研究科, =814-0198 福岡県福岡市城南区別府 5-7-1 (Graduate School of Health and Nutri- \\ tion Sciences, Nakamura Gakuen University Graduate School, 5-7-1 Befu, Jounan-ku, Fukuoka, Fukuoka 814-0198, \\ Japan) \\ 2福岡リゾート\&スポーツ専門学校, † 812-0013 福岡県福岡市博多区博多駅東1-16-27 (Fukuoka College of Resort \& \\ Sport, 1-16-27 Hakatahigashi, Hakata-ku, Fukuoka, Fukuoka 812-0013, Japan) \\ ${ }^{3}$ 中村学園大学栄養科学部, ₹814-0198 福岡県福岡市城南区別府 5-7-1 (Faculty of Nutritional Sciences, Nakamura Gakuen \\ University, 5-7-1 Befu, Jounan-ku, Fukuoka, Fukuoka 814-0198, Japan) \\ 4 福同大学ポーツ科学部, = 814-0180 福岡県福岡市城南区七隈8-19-1 (Fukuoka University, Faculty of Sports and Health \\ Science, 8-19-1 Nanakuma, Jonan-ku, Fukuoka, Fukuoka 814-0180, Japan)
}

Received: August 6, 2018 / Accepted: October 23, 2018

\begin{abstract}
This study aimed to explore the association between various levels of trainingenergy expenditure (TrEE) and nutritional response during the phases of periodization among male collegiate rugby players. Seventeen Japanese male collegiate rugby players were enrolled in the study. Their TrEE and dietary intake were assessed each day during three separate microcycle training phases in the preparatory phase of periodization (P1 and P2: general training phase consisting of two sessions per day over the term during which the school held classes and during a summer vacation, respectively; and P3: intensive training phase consisting of four sessions per day during a summer vacation) using the factorial method and dietary records, respectively. The TrEE for P3 (1644 $\pm 273 \mathrm{kcal})$ was significantly higher than that for P1 $(891 \pm 230$ kcal). However, the total energy intake (EI) for P3 (3274 $\pm 889 \mathrm{kcal})$ was significantly lower than that for P1 $(3978 \pm 938 \mathrm{kcal})$. The daytime (after waking in the morning and before the evening training session) EI ( $242 \pm 159 \mathrm{kcal})$ and protein intake $(19 \pm 12 \mathrm{~g})$ from the 'high-protein foods group' during P3 was significantly reduced compared with that during P1 (465 $\pm 252 \mathrm{kcal}$, $37 \pm 15 \mathrm{~g}$ ), whereas, EI and carbohydrate intake from the 'supplements group' of P3 was significantly increased compared with P1. The increased TrEE during P3 was not compensated by EI; instead, there was a decreased nutrient intake from the high-protein foods group and increased intake from the supplements group. The time of day of multiple or intensive training sessions, i.e. different TrEE, might affect the food choices made by male rugby players.
\end{abstract}

Jpn J Phys Fitness Sports Med, 68(1): 71-82 (2019)

Keywords : appetite, energy deficiency, food intake, sports nutrition, training periodization

\section{緒言}

Periodization（期分け）を勘案したトレーニング（Tr） 戦略は, アスリートが望ましい体組成や体力を獲得し, かつ傷害やオーバーTrを回避する等のコンディショニ ングに有効である ${ }^{1,2)}$ 。一般的な Periodization モデルは, 1 年あるいは半年間程度を 1 サイクル (マクロサイクル)

※ Corresponding Author
とし「準備期（鍛練期：プレシーズン）」，「試合期（シー ズン)」,「移行期（オフシーズン）」などの数カ月ごとの 時期（メゾサイクル）に区分される ${ }^{1)}$ 。さらに，各メゾサ イクルは，週あるいは1日単位のミクロサイクルに区分 される1)。ところで，ラグビー競技に扔けるパフォーマ ンスは, 諸体力が密接に関連し, 除脂肪量をはじめとし た体組成もその一要素である ${ }^{3)}$ 。また, 体重が重い選手 では傷害発生リスクが低い可能性があるため ${ }^{4)}$, 除脂肪 量の増加は競技生命を延伸するための身体的条件の一つ 
とも考えられる. しかし，オーストラリアのナショナル トップリーグや欧州のスーパーリーグの選手を対象とし た先行研究 ${ }^{5-7)} に$ 扔いて, 試合期に除脂肪量が減少する というネガティブな身体変化が報告されており, 試合期 へ移行する前の準備期に如何に除脂肪量を維持・増加す るかがラグビー選手の Tr計画に扔ける重要な課題であ ることが指摘されている ${ }^{5,8)}$.

体重および体組成の変化はエネルギー出納により影響 を受けるが，スポーツ競技者に抢いては，Trを主体とし た身体活動量に合わせた栄養戦略を行うことが望ましい 体組成を獲得する鍵となる ${ }^{9}$. すなわち, 競技現場におけ る栄養補給計画では, 例えば準備期でも Trを行う日と休 息日，あるいはTrが激しい日と緩やかな日といったミク ロサイクル毎に要求されるエネルギー・栄養素量を見積 もり, 選手の $\operatorname{Tr}$ 目的に合せた食事を考えることが基本と なる。しかし，スポーツ競技者の食事パタンや栄養摂取

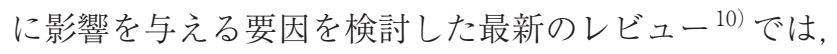
各サイクルによってエネルギーや栄養素の必要量が異な るにも関わらず，それらを充足するための食事調整が実 施できていないことが示唆されており, 必ずしもスポー ツ競技者に対する栄養補給計画の基本が実行されていな い可能性が懸念される。ただし，このレビューは，10〜 19 歳の柔道, サッカー, 水泳等の限られた年代・競技 者を対象に，主に試合期に調查されたわずか 6 本の文献 を基に推察されたという研究の限界点が考えられる。つ まり, Trによる活動量の変化と食事の関連性は, 競技特 性や調查時期, 年齢, 性別により影響を受ける可能性が 否定できない，ところが，我々が文献データベース（医 学中央雑誌, CiNii, PubMed）で調べた限り, ラグビー選 手のエネルギー消費量と栄養素等摂取量を調查した先行 研究は僅かであり, その中でも Periodizationのミクロサ イクルの視点から調査された先行研究は, 欧州プロラグ ビー選手の試合期の活動量と食事摂取量の変動を報告し た 1 編 $^{11)}$ のみであった。ささらに, 最も $\operatorname{Tr}$ 量が高まると 考えられる準備期の活動量と食事の動態を調查した先行 研究, また, 日本人のラグビー選手を対象に検討した調 査は皆無であった。

一方, 夏季強化期や激しい練習が日々繰り返される時 期では，選手の食欲が低下することが経験的に知られて いる ${ }^{12,13)}$. また，大学ラグビー選手を対象とした外傷発 生は, 練習量が他の時期に比して多くなる準備期の中で もより強化される時期にあたる 8 月に多く，その要因の 一つに食欲の減退による栄養摂取不足が推察されている が $^{14)}, \operatorname{Tr}$ 量や食事摂取量のデー夕は示されていない. 上 述の通り Periodizationのミクロサイクルの視点による 先行研究自体が不足しており, ラグビー競技に扔いても, 準備期の Tr量の増大による一時的なエネルギー消費増 加に伴う食欲あるいは食行動への影響に関するエビデン
スを得ることは急務である。

以上の観点より, 本研究の目的は, 日本人大学男子ラ グビー選手の準備期に関してミクロサイクルの視点に立 ち, 実際のフィールド環境下に扔ける $\mathrm{Tr}$ 量の差異と栄 養素等摂取量の関連性について明らかにすることであっ た，加えて，食事内容への影響を選手が選択する食品群 の視点から検討した，実際のフィールド環境下において， Trによる栄養素等摂取量や食品選択への影響を明らか にすることは，ラグビー競技に扔けるパフォーマンス向 上のための体づくりを目的としたスポーツ栄養マネジメ ント遂行にあたり，栄養補給方法の提案抢よび選手の自 立に向けた栄養教育へ展開するための基礎的デー夕にな ると期待できる.

\section{方法}

対象者 A大学男子ラグビー部に所属する18名を対象者 候補とし, 内 1 名が調查期間初期に退部したため, 最終 解析対象者を 17 名とした (年齢 $20.2 \pm 1.2$ 歳, 身長 $173.2 \pm 7.5$ $\mathrm{cm}$, 競技経験年数 $10.2 \pm 4.0$ 年; バックス 7 名, フォワード 10名)。なお，体重は調查した 3 つの期間（Phase）(以下 「調查期間」を参照)の夕練前に測定した (Phase 1:78.9 $\pm 12.1 \mathrm{~kg}$, Phase $2: 79.2 \pm 12.9 \mathrm{~kg}$, Phase $3: 78.6 \pm 12.9$ $\mathrm{kg}$ )。選手の居住形態は, 実家 5 名, 一人暮らし 7 名, 寮 5 名であった，本研究の全てのプロトコルは中村学園大 学倫理審査委員会の承認を得た (倫理-11-001). 対象者 には，事前に研究の趣旨と方法を口頭㧍よび文書にて説 明した上で，書面による同意を得た，なお，対象者が未成 年の場合にはその保護者からも書面による同意を得た。

調査期間 調査は, 大学ラグビーの年間の Periodization のうち, 地域学生リーグ戦開始前の準備期において, ミ クロサイクルの視点から $\operatorname{Tr}$ 内容の異なる次の 3 つの期 間に実施した。なお，合宿等で生活形態が急変した場合 には，自炊や購入等自ら主体的に食事を準備するか，寮 や実家暮らし等で自分以外㖷供してもらうかといっ た食事へのアクセス手段が普段と異なる可能性が危惧さ れるため, 調査は各対象者の食環境が同一となる A大学 内での練習実施日に限定した：大学講義期間中で 1 日 2 回の練習が行われる通常練習期間の一部である 7 月 3 日〜11日 (Phase 1：以下, P1 とする), 夏季休暇中で 1 日 2 回練習が行われた 8 月 3 日〜 10日（Phase 2：以下， P2 とする) および強化合宿開始前（8月13日～) に1日 4 回練習が行われた 8 月 11 日〜 12 日（Phase 3：以下, P3 とする) であった。調查は各Phaseにつき各選手 1 日 に限定し実施した（計 3 日間/選手, 調査日；P1：7/9も しくは7/10, P2：8/5もしくは8/7, P3：8/11). 各Phase の TrスケジュールはTable 1に示した。なお，各Phase の調査実施日に扮けるA大学ラグビー場の環境について 
熱中症指標計（WBGT-203A ; 京都電子工業）を用い評 価したところ, P2の夕練前の湿球黒球温度（Wet-Buld Globe Temperature：WBGT) は $30.3^{\circ} \mathrm{C}$ で厳重警戒レべ ル(激しい運動は禁止) $)^{15)}$ を示したが, P1のWBGTは $25.6^{\circ} \mathrm{C}, \mathrm{P} 3$ は $27.9^{\circ} \mathrm{C}$ と共に $28^{\circ} \mathrm{C}$ 未満であり, 警戒レベル (積極的に休劶 $)^{15}$ であった。

\section{調査項目}

\section{身体活動量調査}

日常活動量は，Trと生活活動を評価した。Trは，調 査実施日の練習内容を全て調査員掞よび対象部のマネー ジャーが目視し, 練習の種類と実施時間をリアルタイム に記録した。練習の種類は「身体活動のメッッ（METs） 表」16) に記載されている類似の個別活動の Metabolic equivalents (METs) 值へ置き換えた。ささらに, METs值 に各活動実施時間と各Phaseの練習開始前に測定した各 選手の体重を乗じ，Trによるエネルギー消費量（以下 $\operatorname{Tr}$ 量）を次の式より算出した：

$\{(\text { 各METs 值 }-1) \times \text { 時間 }(\text { 時 }) \times \text { 体重 }(\mathrm{kg}) \times 1.05\}^{17)}$.

次に, Trを除く生活活動量の評価は，選手自身に回答 を依頼した世界標準化身体活動質問票（Global Physical Activity Questionnaire：(GPAQ) ${ }^{18)}$ の日本語版 ${ }^{19)}$ を用い た. GPAQは, 日常の身体活動を仕事(学業を含む), 移動, 余㗇時間（スポーツ活動を含む）の各生活場面別につい て, 特に $3 \mathrm{METs}$ 以上の強度の活動に焦点をあて質問す る尺度であり，日常身体活動水準の評価に执いて十分な 信頼性と妥当性が証明されている手法である ${ }^{18,19)}$ ，本研 究では当該質問紙の設問項目の中から Trに該当する以 外の項目（仕事と移動の設問）の回答より得られた身体 活動量 (メッッ・時) を1 日あたりに換算し，上述の $\mathrm{Tr}$ 量と同様の式を用いて生活活動エネルギー消費量を算出 した.

\section{食事調査}

各Phaseの調查実施日の 1 日に摂食した食事（朝食· 昼食・夕食・間食・夜食・飲久物すべて）を選手自身で 写真撮影した上で，記録用紙へ記入するよう依頼した。 後日，面談を実施し，写真抢よび記録用紙並びにサイズ の基準となる食器抢よび実物大食品カードを用い，食事 の内容や量を確認した。栄養素等摂取量は, エクセル栄 養君(Ver.8.0, 建帛社)を用い算出した. 得られたデー夕は, 栄養密度法にて，エネルギー産生栄養素であるたんぱく 質, 脂質, 炭水化物は, 総エネルギーに占める割合（エ ネルギー比率：\%E), その他の栄養素については総エネ ルギー摂取 $1000 \mathrm{kcal}$ 当たりの摂取量へ換算した。たん ぱく質と炭水化物については, 体重当たりの摂取量も算 出した。ささらに, 食事内容を次の手順で食品群別に分析 した．国立スポーツ科学センターのサプリメント分類 ${ }^{20)}$ に基づき, サプリメント食品群とサプリメント以外の食 品群に分類した. サプリメント以外の食品群については, 平成 26 年度の国民健康·栄養調査報告書 ${ }^{21)}$ の食品群別表 中分類に基づき 33 食品群に分類した。ささらに，食事バラ ンスガイド ${ }^{22}$ およよ゙小・中学生のスポーツ栄養ガイド ${ }^{23)}$ を参考に, サプリメント食品群を含め 8 食品群に分類し た（ I VVII群：Table 2). 食品群別の摂取量に関しては, それぞれの食品群からのエネルギー量およびたんぱく 質, 脂質, 炭水化物の重量を算出した.

統計解析 解析結果は, 平均值士標準偏差で示した。 Tr 量は 1 日の総量に加え, 早朝練習から夕練前まで（以下, 日中 $\operatorname{Tr}$ 量とする) と夕練のみ（以下, 夕練 $\operatorname{Tr}$ 量とする) に分けて分析を行った，栄養素等摄取量も同様に，1日 の総量に加え, 起床後から夕練開始前まで（以下, 日中 摂取量とする）と夕練終了直後から就寝前まで（以下, 夕練以降摂取量とする）に分けて分析を行った。

$\operatorname{Tr}$ 量, 生活活動量, 食事摂取量, 密度法による摂取

Table 1. Outline of the training schedule during three training microcycle phases in the preparatory phase.

\begin{tabular}{cccc}
\hline Time of day & Phase 1 & Phase 2 & Phase 3 \\
\hline Early morning & Gym & & Run \\
Between morning and noon & & Fitness & Gym \\
Between noon and evening & & Fitness \\
Evening & Fitness \& Rugby & Rugby & Rugby \\
\hline
\end{tabular}

Phase 1: General training phase consisted of two sessions per day over the term during which the school held classes.

Phase 2: General training phase consisted of two sessions per day during a summer vacation.

Phase 3: Intensive training phase consisted of four sessions per day during a summer vacation. 
Table 2. The classification of food groups.

\begin{tabular}{|c|c|c|}
\hline & Food group & $\begin{array}{c}\text { Food grouping used: medium classification in NHNS } \\
\text { or supplement classification in JISS }\end{array}$ \\
\hline I group & Cereals (High carbohydrate foods) & $\begin{array}{l}\text { Rice and Rice products } \\
\text { Wheat flour and Wheat products } \\
\text { Other cereals and Other creal products }\end{array}$ \\
\hline II group & High protein foods & $\begin{array}{l}\text { Soybeans and Soybean products } \\
\text { Other pulses and Pulse products } \\
\text { Raw fishes and Shellfishes } \\
\text { Seafood and Processed products } \\
\text { Animal meats } \\
\text { Poultries } \\
\text { Offals } \\
\text { Others } \\
\text { Eggs }\end{array}$ \\
\hline III group & Vegetables & $\begin{array}{l}\text { Potatoes and Potato products } \\
\text { Starches and Starch products } \\
\text { Nuts and Seeds } \\
\text { Green and yellow vegetables } \\
\text { Other Vegetables } \\
\text { Vegetable juices } \\
\text { Pickles } \\
\text { Mushrooms } \\
\text { Algae }\end{array}$ \\
\hline IV group & Milk and Dairy products & $\begin{array}{l}\text { Milk and Dairy products } \\
\text { Others }\end{array}$ \\
\hline V group & Fruits & $\begin{array}{l}\text { Fruits } \\
\text { Jams } \\
\text { Fruit juices and Fruit juice beverages }\end{array}$ \\
\hline VI group & Snacks, Confection and Beverages & $\begin{array}{l}\text { Confectioneries } \\
\text { Sugars and Sweeteners } \\
\text { Other beverages }\end{array}$ \\
\hline VII group & Others & $\begin{array}{l}\text { Alcohoic beverages } \\
\text { Fats and Oils } \\
\text { Seasonings } \\
\text { Spices and Others }\end{array}$ \\
\hline VIII group & Supplements & $\begin{array}{l}\text { Dietary Supplements and Sports Foods } \\
\text { Ergogenic Aids }\end{array}$ \\
\hline
\end{tabular}

Groups I to VII were classified based on the classification of National Health and Nutrition Survey (NHNS) ${ }^{21)}$.

Group VIII was classified followed by the supplement classification of Japan Institute of Sports Sciences $\left(\right.$ JISS) ${ }^{20)}$.

量, 食品群別摂取量の 3 つのPhaseの比較には, 反復測 定による一元配置分散分析を用い，有意なPhase 間の差 が認められた場合には, P1を対象值としたDunnett法に よる post hoc検定を行った。また，P1とP2およびP3の 間の差の程度を示すために対応のある 2 群に打ける効果 量Cohen's $\mathrm{d}_{z}^{24)}$ を算出し, 0.20 以上を小さな効果, 0.50 以 上を中程度の効果, 0.80 以上を大きな効果と解釈した ${ }^{24)}$. さらに, 有意なPhase 間の差が認められた 1 日の栄養素 等摂取量に関して，そのPhase 間の差に対する食品群別 摂取量の影響を検討するために, 従属変数に 1 日の栄養 素等摂取量のPhase 間の差（P1-対象のPhase）とし, 独立変数に食品群別摂取量のPhase 間の差とした単相関 分析を行いSpearmanの順位相関係数 $(r)$ を算出した. 全ての統計処理は, IBM SPSS Statistics Version 22.0 (日 本アイ・ビー・エム）を用いた，統計学的有意水準は $5 \%$ とした

\section{結 果}

身体活動量 生活活動エネルギー消費量に関して, Phase間に有意な差は認められなかった（P1：157士179 kcal, P2 : $224 \pm 339 \mathrm{kcal}, \mathrm{P} 3: 222 \pm 337 \mathrm{kcal} ; p=0.381$ ). 一方, 総 $\mathrm{Tr}$ 量ではPhase 間に有意な差が認められ，P1

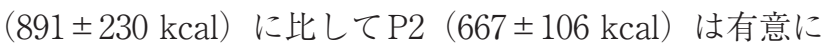
低値を示し, P3（1644 $\pm 273 \mathrm{kcal} ）$ は有意に高值を示し た（Fig. 1)。さらに，2つの時間帯毎の分析では，日

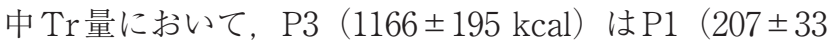
kcal）より有意に高值を示した。 しかし, 夕練 $\mathrm{Tr}$ 量では,

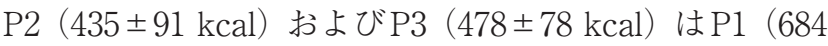
$\pm 214 \mathrm{kcal})$ より有意に低值を示した。

エネルギー・栄養素摂取量 1 日の総摂取量に関して, P3の総エネルギー摂取量はP1に比して有意に低值を示 

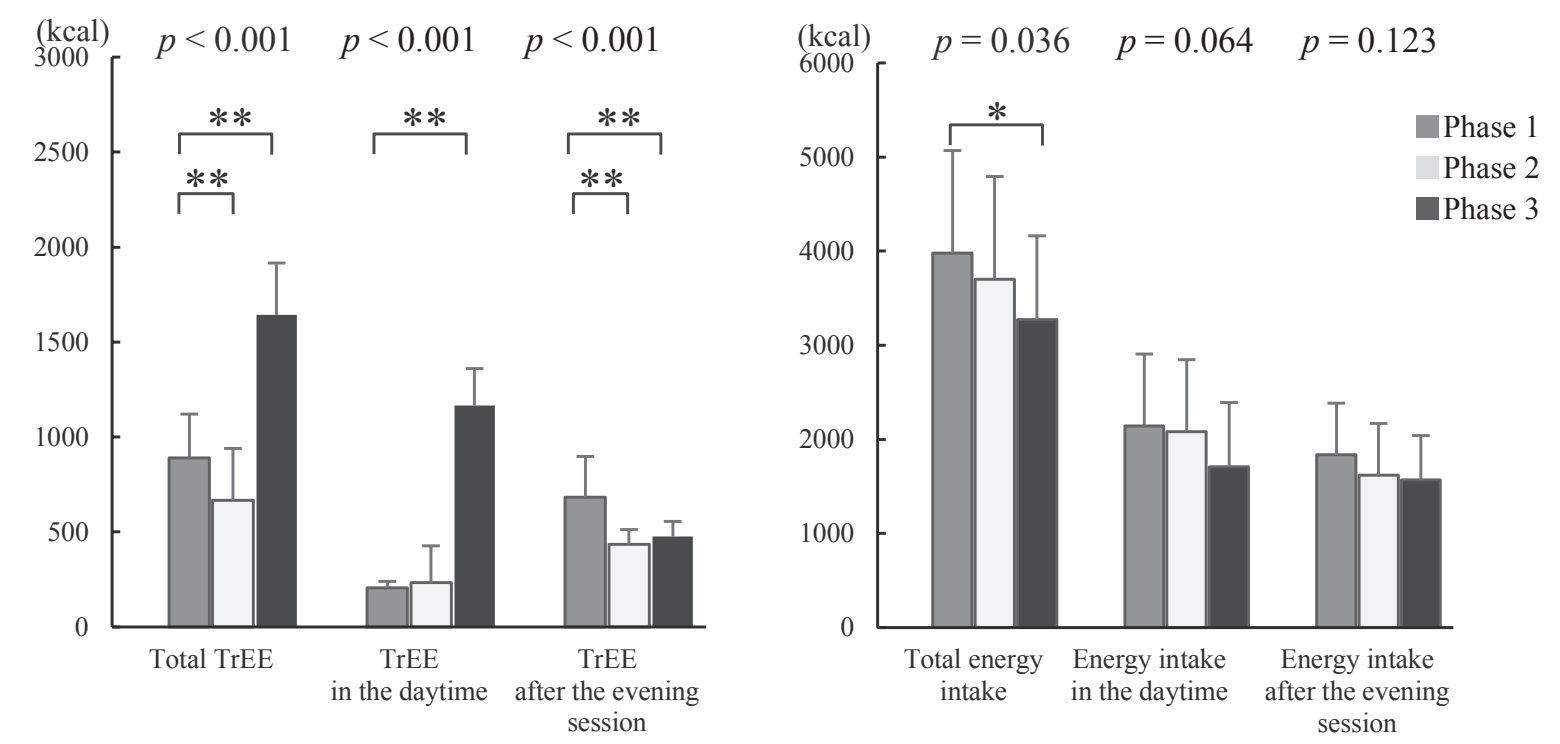

Fig. 1 Training-related energy expenditure (Left) and energy intake (Right) of collegiate male rugby players during three microcycle training phases in the preparatory phase.

$p$ values were derived from one-way repeated ANOVA. ${ }^{* *} p<0.01,{ }^{*} p<0.05$ : Significantly different from Phase1 (according to Dunnett's post hoc test).

TrEE: training-related energy expenditure.

In the daytime: after waking in the morning and immediately before the evening training session.

Phase 1: General training phase consisted of two sessions per day over the term during which the school held classes.

Phase 2: General training phase consisted of two sessions per day during a summer vacation.

Phase 3: Intensive training phase consisted of four sessions per day during a summer vacation.

したが, P2 と P1に有意な差は認められなかった (Fig. 1).

Table 3 に摂取した各栄養素量を示した。エネルギー産 生栄養素に扔いて, P3の総たんぱく質摂取量のみP1よ り有意に低値を示した。 日中の㩒取量に関して, エネル ギー摂取量でPhase 間に差の傾向が認められ, P3が最も 低い平均値を示したが, post hoc 検定では有意な差は認 められなかったＰ3のたんぱく質はP1より有意に低值 を示した。脂質摂取量はPhase 間に有意な差が示され, P3で最も低い值を示したものの post hoc 検定では差は検 出されなかった. 夕練以降の摂取量に関して, エネルギー およびエネルギー産生栄養素にPhase 間の有意な差は認 められなかった。

次に, Table 4に密度法にて算出した摂取量を示した。 1 日の総摂取量に関して, P3のたんぱく質エネルギー比 率とナイアシン当量密度, 体重当たりのたんぱく質, お よびP2のビタミン $\mathrm{B}_{2}$ 密度は, $\mathrm{P} 1$ に比して有意に低い值 を示した。 日中の摂取量に関して，P3のたんぱく質エ ネルギー比率, 鉄密度, ビタミン D密度, および $\mathrm{P} 2$ の ビタミンD密度は，P1に比して有意に低い值を示した。 一方, P3の炭水化物エネルギー比率はP1より有意に高 い值を示した。しかし, 夕練以降の摂取量ではいずれの 項目もPhase間の有意な差を認めなかった.

食品群別の栄養素等摂取量 Table 5 に, 8 食品群別の
エネルギーならびにエネルギー産生栄養素の㩒取量を示 した。 1 日総量では, P3のII群からのたんぱく質摂取 量は, P1に比して有意に低值を示した. P3のVIII群からの エネルギー量抢よび炭水化物は $\mathrm{P} 1$ に比して有意に高值 を示した，日中の摂取に着目すると，P3の群からのエ ネルギー量, たんぱく質, 炭水化物㧍よびP2のII群から の炭水化物は, P1に比して有意に低值を示した，吕群に 関して, P2のエネルギー量はP1より有意に高值を示し, P2の炭水化物はP1に比して高值傾向を示した. VII群に 関して, P2のエネルギー量はP1より有意に高值を示し, P3のたんぱく質はP1より有意に低值を示した。VIII群に 関して, P3のエネルギー量および炭水化物はP1に比し て有意に高值を示した，一方，夕練以降においてはいず れの項目もPhase間に有意な差は認められなかった.

栄養素等摂取量のPhase間の差に対する各食品群別摂取 量の影響 上述したP3 と P1の 1 日の総エネルギー摂取 量の差に関して, 各食品群の摂取状況の変化がどのよう に影響しているかを調べるために, 総エネルギー摂取量 ならびに各食品群から摂取されたエネルギー量のPhase 間の差 $(\mathrm{P} 1-\mathrm{P} 3)$ の単相関分析を行った。総エネルギー 摂取量のPhase 間差に対して, 日中 I 群および日中VII群

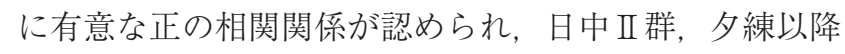
IV 群，夕練以降 VII群に相関傾向が認められた（Fig, 2). 

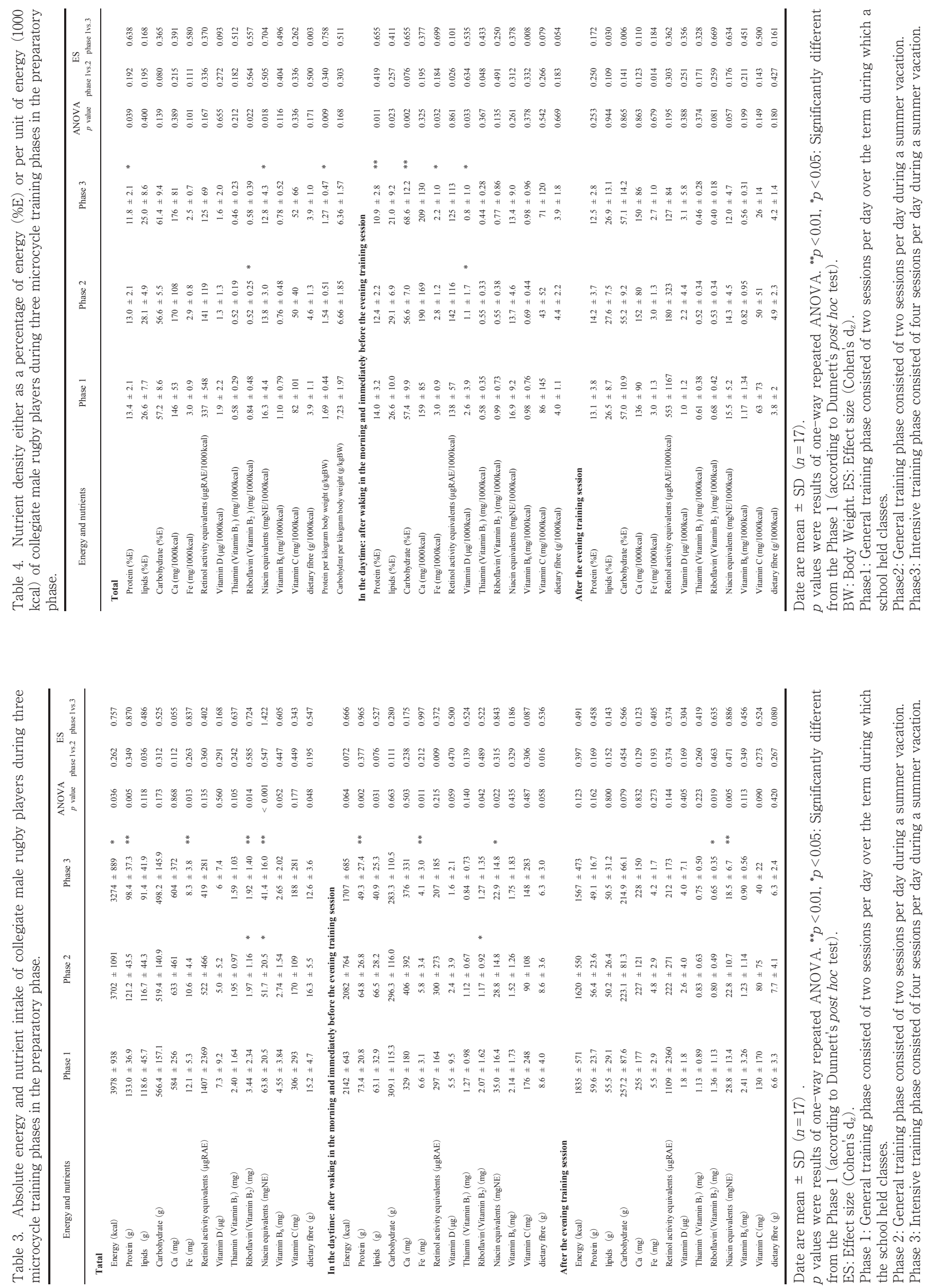


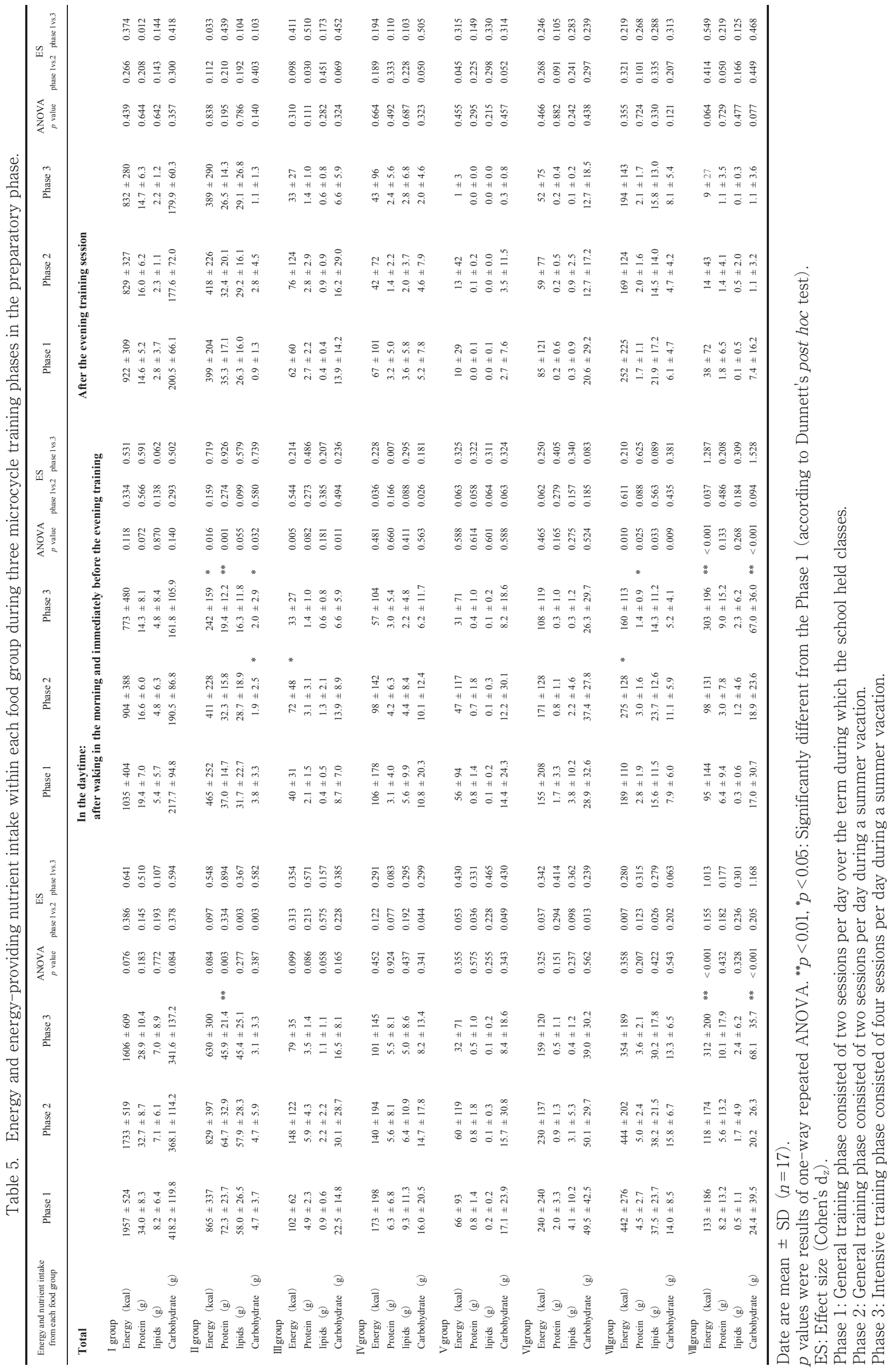


同様に 1 日のたんぱく質摂取量の差に関しては, 日中II 群と夕練以降 II 群から摄取したたんぱく質の Phase 間の 差と有意な正の相関関係（日中 II 群 : $r=0.598, p=0.011$ および夕練以降 II 群 : $r=0.694, p=0.002)$, 日中VI群から 摂取したたんぱく質の Phase 間の差と有意な負の相関関 係 $(r=-0.549, p=0.023)$ が認められた.

\section{考察}

本研究は, Periodizationのミクロサイクルの視点より, 日本人大学男子ラグビー選手の準備期に㧍ける Tr 量の 差異が，栄養素等摂取量掞よび食品群別摂取量に及ぼす 影響を検討した初めての報告であった。生活活動エネル ギー消費量に有意なPhase 間の差は認められなかったた め, 各Phaseに打ける身体活動エネルギー消費量の変動 は Tr内容の差異によるものと考えられた。通常練習期 間の一部であるP1を基準として, 大学夏季休㗇中の練習 期である $\mathrm{P} 2$ およびP3を比較した結果, P3では 1 日の Tr の頻度と量が増加したことに伴いエネルギー消費量が増 大したにも関わらず, 総エネルギー摂取量はそれに追従 せずむしろ減少することが明らかとなった。また，日中 摂取量と夕練以降摂取量の時間帯に分けた分析の結果, P3はP1に比べ, 日中の「II群：たんぱく質を多く含む群」 によるたんぱく質量が減少した一方で, 日中の「VIII群： サプリメント食品群」によるエネルギーと炭水化物の増 加が認められ, 炭水化物エネルギー比率も高值であった。 しかし, このようなサプリメント食品群の増加をもって しても，P3のエネルギー消費量の増加に見合うような 1 日の総エネルギー摂取量増加には至らなかった。このよ うに $\mathrm{Tr}$ 量の差異は, 選択する食品ひいてはエネルギー 産生栄養素バランスならびに総エネルギー摂取量に影響 を及ぼすことが示唆された。夏季強化練習などの激しい 練習が繰り返される時期では選手に食欲低下に関連した 愁訴がみられることが経験的に知られている ${ }^{12,13)}$. 本結 果は, 実際の栄養素等摂取量の変化の視点から $\mathrm{Tr}$ 量の 増加に対して摂食行動が追従しないことを客観的に示し たオリジナルの知見である。 また, 柔道, サッカー, 競 泳の青少年選手では，Tr量が変動するメゾサイクルに おいて栄養素の必要量の変化に応じた食事調整が実施で きていないことを示唆した最新の報告 ${ }^{11)} に$ 関して, 本研 究はミクロサイクルの視点からそれを支持するものであ る.すすなわち, $\operatorname{Tr}$ 量の変動に応じた適切な食事・栄養補 給は多くのスポーツ選手に扔ける共通の課題であること が示唆された。

\section{トレーニング量の差異が栄養素等摂取量に及ぼす影響}

1 日の $\operatorname{Tr}$ 量の増大に食事摂取量が随伴しなかった要 因の一つとして, 高強度運動後に引き起こされるExercise-induced anorexia (運動誘発性食欲不振) ${ }^{25,26}$ の影響
が推察された。この高強度運動後の摂食行動抑制は運動 直後 30 分程度持続するものの運動後 $2 \sim 9$ 時間後には消 失することが報告されている ${ }^{26)}$. 準備期の 3 つの Phase おいて, P3は他のPhaseよりも日中 Trの頻度と量が高 められ，1 日の総 $\operatorname{Tr}$ 量の平均值が約 2 倍に増加してい たにも関わらず, 総エネルギー摂取量は随伴した変化を せずむしろ減少していた（Fig. 1)。また，夕練以降の摂 取量にPhase間の差は認められず，P3の日中摂取量への み影響が認められたことも注目すべき点である。P3の日 中は, 試合期へ向けて体力増強㧍よび技術向上・チーム 戦術理解の双方を強化する $\operatorname{Tr}$ が複数回実施されたため, Tr 間の休息時間は 2 時間程度であった。つまり，P3は， 毎回の Tr後の運動誘発性食欲不振によって一時的に食 事摂取量が抑制され，食欲が回復する前に次の Trが開 始してしまうために，日中に充分な食事が摂取できな かった可能性が推察された。一方, P2ではP1と同様に 午前中の $\mathrm{Tr}$ 終了から夕練開始まで 5 時間以上の時間が あり, 食欲回復と食事調達のための充分な時間を確保す ることが可能であったと推察された。なお， 3 つのTr 期の夕練前の気候に関して, P2が最もWBGT值が高い 厳重警戒の水準であった (方法「調査期間」を参照). すなわち，食事摂取量への影響は，気候よりも上述の Tr量が重要な因子であったと考えられた。このように 本研究対象者に扔いて, 相対的エネルギー不足を引き起 こすPhaseがある可能性が懸念された，エネルギー消費 量に見合ったエネルギーを摂取できない場合はエネル ギー源として体組織からのたんぱく質動員量が増加する ため, $\operatorname{Tr}$ 量の変動によるエネルギー消費量の増加分に 摂取量が追従しなかったという事実は，一定期間この状 態が継続した場合, 選手の体重㧍よび除脂肪量の減少を 誘引儿, これら体格指標と密接に関連する競技パフォー マンス低下や傷害発生 ${ }^{3)}$ あいはRelative Energy Deficiency in Sports（RED-S：スポーツに抒ける相対的エ ネルギー不足 ${ }^{27)}$ といった選手生命や生涯に亘る健康保 持に対するリスクを高めることが危惧される.

スポーツ競技者の栄養に関するガイドライン ${ }^{28)}$ では, $\mathrm{P} 1$ 抢よびP2の $\mathrm{Tr}$ 量に相当する 1 日 $1 \sim 3$ 時間の中〜高 強度運動時の糖質摂取目標值として体重 $1 \mathrm{~kg}$ 当たり 1 日に $6 \sim 10 \mathrm{~g}, \quad \mathrm{P} 3$ の $\operatorname{Tr}$ 量に相当する 1 日 $4 \sim 5$ 時間の 中〜高強度運動時では $8 \sim 12 \mathrm{~g}$ を推奨している. P3では 炭水化物を多く含むサプリメント食品の摂取がP1より 増加していたにも関わらず, 炭水化物摂取量は6.4 g士 1.6 $\mathrm{g} / \mathrm{kg}$ と目標值を大幅に下回っていた。 さらに, 1 日の体

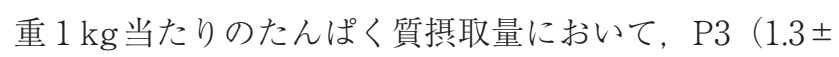

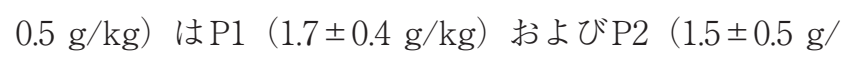
$\mathrm{kg}$ ）に比べ低值を示した（Table 4)。スポーツ選手が体 内のたんぱく質代謝やリモデリングを維持するには, 一 般的に 1 日に1.2 2.0 g/ $\mathrm{kg}$ のたんぱく質摂取が推奨さ 

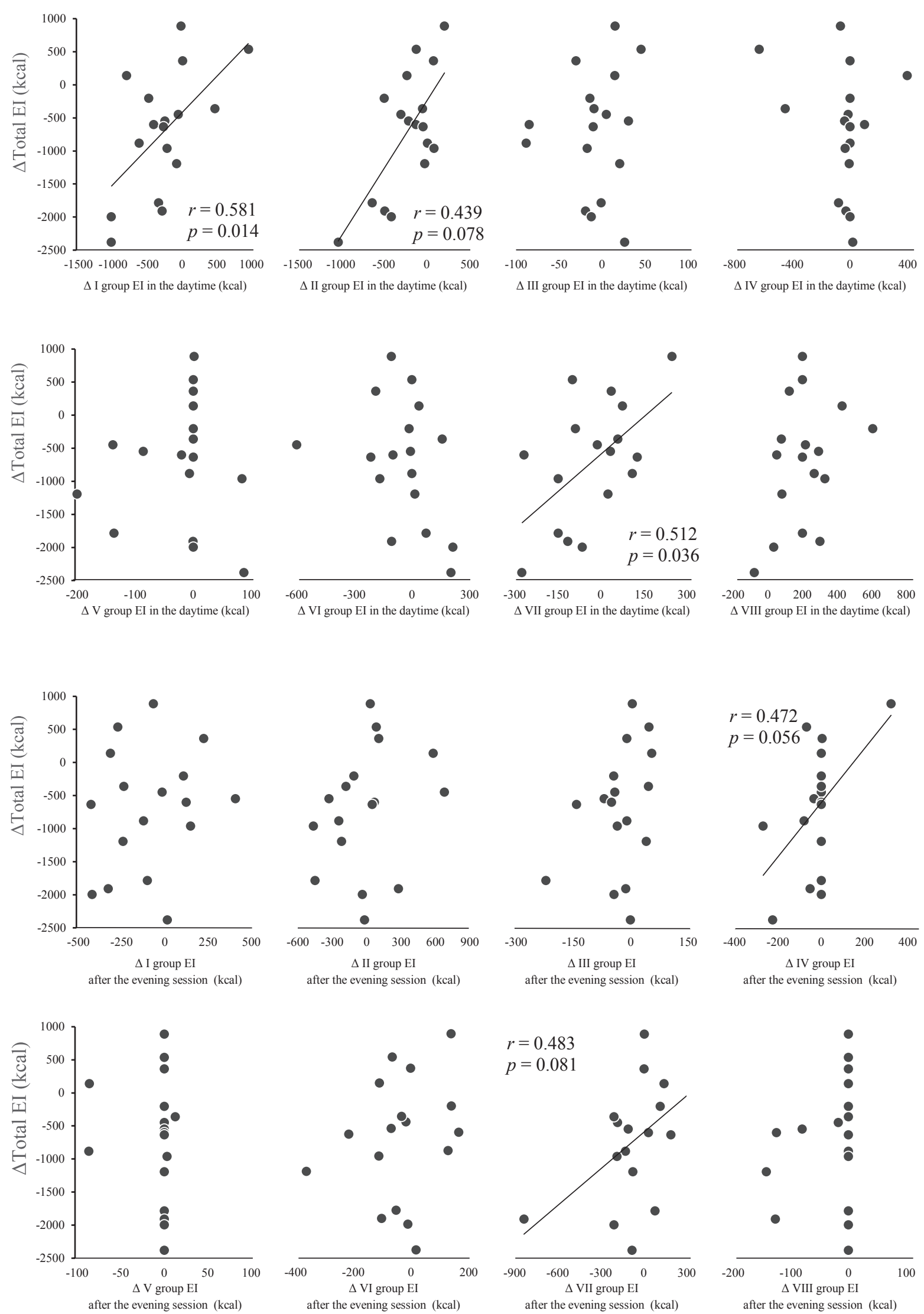

Fig. 2 Relationship between differences of total energy intake (EI) and EI within each food group in the daytime (Upper half) and after the evening training session (Lower half part)

Spearman's rank correlation coefficients $(r)$ were calculated.

$\Delta$ : difference (Phase1 minus Phase3); group I: cereals; group II: high-protein foods; group III: vegetables; group IV: milk and dairy products; group V: fruits; group VI: snacks; group VII: other; group VIII: supplements.

in the daytime: after waking in the morning and immediately before the evening training session. 
れている ${ }^{28)}$. 本研究の対象者では各Phase ともこの推奨 量の範囲内であったが, 短期間の強化 $\mathrm{Tr}$ 実施の場合は, より多くのたんぱく質摂取が必要なことも指摘されてお $り^{28)}$ ，体力増強打よび技術力向上を目的とし体重打よ び除脂肪量の増加を必要とする準備期 ${ }^{8}$, 特にP3で他の Phaseより低值を示したことに留意する必要があろう.

\section{トレーニング量の差異が食品群別摂取量に及ぼす影響}

食品群別摂取量に関して (Table 5), P3では, 日中に 「II群：たんぱく質を多く含む食品群」から摂取したた んぱく質量が他のPhaseの半分近くにまで減少し, 特に P1 と P3の差の程度は 0.926 と大きな効果量を示した。一 方で，P3の日中に打ける「细群：サプリメント食品群」 からのエネルギーと炭水化物の摂取量は他のPhaseの 3 倍以上に増加し, P1 と P3の差には大きな効果量（エネ ルギー：1.013, 炭水化物：1.168）が認められた。また, 総エネルギー摂取量におけるP 3 とP1との差は, 日中の 「I 群：炭水化物を多く含む食品」と調理に使用した油 脂類等を含む「VII群：その他の食品群」から摂取したエ ネルギー量の当該Phase 間の差と有意に関連することが 認められ (Fig. 2: $r=0.581$ および $r=0.512)$, 総エネルギー 摂取量の減少は, 特に日中の食事選択に起因している可 能性が考えられた，以上の結果は, Tr量の差異が選手の 選択する食事内容に影響し，それに伴いエネルギー摂取 量にも影響を及ぼすことを示唆する本研究オリジナルの 知見である。運動が食事内容の選択に影響を及ぼすこと を示唆する興味深い先行研究として, Crabtree DRら ${ }^{29)}$ は, 一過性の高強度運動後に低カロリー食と高カロリー 食の写真を見せた場合, 高カロリー食の写真からの視覚 刺激によって食欲調整に関連すると考えられる脳の一部 活性が抑制されたことを報告している。この先行研究を 勘案すると, P3のような日中に複数回の高強度 $\operatorname{Tr}$ が行 われた際に摂取した食事では，たんぱく質や脂質を含む 主菜を摂取するような比較的高カロリーの食事スタイル を無意識に避け, 脂質含有が少なく炭水化物を豊富に含 むエネルギー補給系のサプリメント食品にアクセスした 可能性が考えられた。このような選手自身の食品群の選 択は, P3の炭水化物エネルギー比率が他の Phaseより 高い食事内容である高炭水化物食に繋がったと考えられ る. Tremblay A ら ${ }^{30)}$ は, 運動後に高脂肪食を摂取した 場合は運動によるエネルギー消費増加分を代償し，高炭 水化物食を摂取した場合は負のエネルギー収支バランス を引き起こすことを示唆しており, 本研究においてP3 のエネルギー摂取量が消費量の増加に随伴しなかった要 因として, このような日中の食品の選択による食事の工 ネルギー産生栄養素バランスへの影響が関与している可 能性も推察された。
本研究の限界として, 第一に, Tr量と生活活動量は, 主 観的観察による要因加算法掞よび質問紙法を用いた点で ある。本調查法は, 測定の厳密性や客観性にそしいという 短所は周知である ${ }^{31)}$. しかし, 質問紙法は先行研究 ${ }^{18,19)}$ で 一定の信頼性と妥当性が担保された手法を採用した，要 因加算法も身体活動評価法の一手法であり, 本研究では 全ての練習を直接観察し練習内容をリアルタイムで選手 個々に評価する工夫を行った。また，1日の総エネル ギー消費量の主要素である基礎代謝量を評価できていな いことも限界点である。しかし, 本研究は比較的短期 間に実施され，かつ各Phaseの体重に大きな差は認めら れなかったことから（方法「対象者」を参照），基礎代 謝量に重大な変動はなかったものと推察される。ささら に, 本研究では Tr後に安静時エネルギー消費量が高ま る Excess Post-exercise Oxygen Consumption (EPOC) を評価していないが，P3ではとりわけEPOCが充進し本 研究で評価したよりも実際にはさらに高いエネルギー消 費を Trに関連して誘引した可能性があり，本研究で懸 念されたエネルギー摂取量が消費量に随伴しない状態は より梁刻であった可能性がある。第二に，本研究の調査 が各Phase とも 1 日ずつのみに限定したことによる食事 調查に扔ける限界点である。習慣的な運動は, 食事摂 取の制御に関わる脳内の神経反応 ${ }^{32}$ おおよびエネルギー 代謝や行動的側面で自動的かつ長期的に適応する ${ }^{33)}$ とが報告されており, 各Phase とも複数日に亘り食事捸 取状況を調查する必要があったかもしれない.しかし 本研究は, 各Phaseで 1 日のみに限定して食事調查を行 うことで確実な食事情報を得ることを意図した。アア ア リートへの食事調査の妥当性について検討した最新のレ ビュー ${ }^{34)}$ では, 食事記録法による4 日以上の食事調査 では，約 19\%過小評価することが報告され，食事調査は 選手にとって負担となり調查が複数日となることが誤差 を誘引すると考えられる。

今後の課題として, 第一に, 食品選択に及ぼすと考え 得る交絡因子についても検討することである。ヒトの食 行動は, 食品入手の利便さや価格, 会食などの外的・社 会的要因, 食事時間带や摄食速度などの摂食パ夕ン, 性 別や身体活動などその他生物学的要因の影響を受けると 考えられている ${ }^{35,36)}$. P3は 1 日を通して練習が頻回に 行われていたため, 食欲や疲労度などの内的要因のみな らず食事を購入あるいは準備する時間の確保が難しいと いった外的要因が食事摂取量に影響した可能性も否定で きない，第二に，準備期に扔けるエネルギー消費量と食 事量をより長期間観察すると共に，体重や体組成あるい は血液生化学検查值によりエネルギー出納とその影響を 評価する必要がある。 


\section{総 括}

本研究は，大学男子ラグビー競技の準備期における夏 季強化練習期間中において Trの頻度と量の増加に伴い エネルギー消費量が増大しても, 総エネルギー摂取量は 追従せずむしろ減少したことを明らかにした。また，日 中の Tr頻度と量が最も高かったP3は, 日中に摂取した 「たんぱく質を多く含む食品群」が減少した一方で「サ プリメント食品群」が増加し, 日中の食事内容は通常練 習日に比べて高炭水化物食に転じていた。しかし，この ようなサプリメント食品群の摂取量の増加をもってして も, $\operatorname{Tr}$ 量の増加に見合う 1 日の総エネルギー摂取量の 増加には至らなかったという重要な事実が示された。さ らに, 夕練以降の食事内容に差が認められなかったこと から, 日中の頻回に亘る中高強度 $\operatorname{Tr}$ の実施が, 食品選択 およびエネルギー産生栄養素バランスに影響し, エネル ギー摂取量の減少を引き起こした可能性が示唆された。 このような Tr量の変化が選手の摂食行動に影響を及ぼ すことを勘案した上で, 特に練習の頻度・量が増す時間 帯（例えば日中）の食事の摂取方法や時間管理を主体と した栄養補給や環境の整備, あるいは選手に対する栄養 教育の実施などの栄養サポート計画を行う必要性が考え られた。

利益相反自己申告 : 申告すべきものはなし

\section{謝 辞}

本研究にご協力いただいた $\mathrm{A}$ 大学ラグビー部の部員およ び鶴丸誠様はじめ関係諸氏に深謝申し上げます。

\section{参考文献}

1) Gamble P. Periodization of training for team sports athletes. Strength Cond J 28: 56-66, 2006.

2) Gabbett TJ. The development and application of an injury prediction model for noncontact, softtissue injuries in elite collision sport athletes. $J$ Strength Cond Res 24: 2593-2603, 2010. doi: 10.1519/ JSC.0b013e3181f19da4.

3) Till K, Scantlebury S, Jones B. Anthropometric and physical qualities of elite male youth rugby league players. Sports Med 47: 2171-2186, 2017. doi: 10.1007/ s40279-017-0745-8.

4) Gabbett TJ, Domrow N. Risk factors for injury in subelite rugby league players. Am J Sports Med 33: 428434, 2005. doi: 10.1177/0363546504268407.

5) Harley JA, Hind K, O'hara JP. Three-compartment body composition changes in elite rugby league players during a super league season, measured by dualenergy X-ray absorptiometry. J Strength Cond Res 25: 1024-1029, 2011. doi: 10.1519/JSC.0b013e3181cc21fb.

6) Georgeson EC, Weeks BK, McLellan C, Beck BR. Sea- sonal change in bone, muscle and fat in professional rugby league players and its relationship to injury: a cohort study. BMJ Open 2: e001400, 2012. doi: 10.1136/ bmjopen-2012-001400.

7) Lees MJ, Oldroyd B, Jones B, Brightmore A, O'Hara JP, Barlow MJ, Till K, Hind K. Three-compartment body composition changes in professional rugby union players over one competitive season: A team and individualized approach. J Clin Densitom 20: 50-57, 2017. doi: 10.1016/j.jocd.2016.04.010.

8) Argus CK, Gill N, Keogh J, Hopkins WG, Beaven CM. Effects of a short-term pre-season training programme on the body composition and anaerobic performance of professional rugby union players. J Sports Sci 28: 679-686, 2010. doi: 10.1080/02640411003645695.

9) Stellingwerff T, Boit MK, Res PT; International Association of Athletics Federations. Nutritional strategies to optimize training and racing in middledistance athletes. J Sports Sci 25: S17-28, 2007. doi: 10.1080/02640410701607213.

10) Noll M, de Mendonça CR, de Souza Rosa LP, Silveira EA. Determinants of eating patterns and nutrient intake among adolescent athletes: a systematic review. Nutr J 16: 46, 2017. doi: 10.1186/s12937-017-0267-0.

11) Morehen JC, Bradley WJ, Clarke J, Twist C, Hambly C, Speakman JR, Morton JP, Close GL. The assessment of total energy expenditure during a 14-day inseason period of professional rugby league players using the doubly labelled water method. Int J Sport Nutr Exerc Metab 26: 464-472, 2016. doi: 10.1123/ijsnem.2015-0335.

12）平岡秀雄, 田村修治, 鈴木昭寿, 荒川正一：運動負荷が血 液性状に及ぼす影響についてーハンドボール選手を対 象としてー, 東海大学紀要, 20: 59-66, 1990.

13）古泉佳代, 川本恵子, 菊地ゆめみ, 田牧一幸, 齊藤隆志: 女子ラクロス部のトレーニング期における体組成変 化を支援する食育の実践, 日本女子体育大学紀要, 45: 105-116, 2015.

14）大石泰輔, 森本晃司, 鈴木健太郎, 漆畑俊哉, 平賀 暁, 内 山達二, 地 英基, 中村龍一, 吉田一希, チャールズ・ロウ, 猪俣弘史, 西機 真, 森 信太郎, 中谷 創, 上野裕一, 山田 睦雄：流通経済大学ラグビー部における2013年度外傷 報告, 流通経済大学スポーツ健康科学部紀要, 8: 69-78, 2015.

15）川原 貴, 伊藤静夫, 井上芳光, 田中英登, 中井誠一, 長谷 川博, 松本孝朗, 安松幹展. スポーツ活動中の熱中症予 防ガイドブック, (4), 公益財団法人日本スポーツ協会, 東京, 2013.

16）国立健康・栄養研究所. 改訂版『身体活動のメッ ツ（METs）表』, 2012. http://www.nibiohn.go.jp/ files/2011mets.pdf（閲覧日2018年 8 月 1 日）

17）厚生労働省. 健康づくりのための身体活動基 準 2013, 2013. http://www.mhlw.go.jp/stf/ houdou/2r9852000002xple-att/2r9852000002xpqt.pdf （閲覧日2018年 8 月 1 日）

18) Bull FC, Maslin TS, Armstrong T. Global physical activity questionnaire (GPAQ): nine country reliability 
and validity study. J Phys Act Health 6: 790-804, 2009. doi: 10.1123/jpah.6.6.790.

19）村瀬訓生, 上田千穂子, 長田卓也, 木目良太郎, 小清水英 司, 勝村俊仁：世界標準化身体活動質問表（GPAQ）お よび国際標準化身体活動質問表 (IPAQ) の信頼性, 妥 当性の検討, 体力科学, 53: 899, 2004.

20）国立スポーツ科学センター、サプリメント@JISS. http://www.jpnsport.go.jp/jiss/supplement/tabid/340/ Default.aspx（閲覧日2015年11月 12 日）

21）厚生労働省. 平成 26 年国民健康 ·栄養調査報告書, 2016. https://www.mhlw.go.jp/bunya/kenkou/eiyou/dl/h26houkoku.pdf（閲覧日2018年 8 月 1 日）

22）農林水産省.「食事バランスガイド」について. http:// www.maff.go.jp/j/balance_guide/（閲覧日 2018年 8 月 1 日）

23）木村典代, こばたてるみ. 食事バランスのととのえ方, 小・中学生のスポーツ栄養ガイドースポーツ食育プログ ラム, 公益財団法人日本体育協会・樋口満監修, こばた てるみら編著, 女子栄養大学出版部, 東京, 17, 2012.

24) Lakens D. Calculating and reporting effect sizes to facilitate cumulative science: a practical primer for ttests and ANOVAs. Front Psychol 4: 863, 2013. doi: 10.3389/fpsyg.2013.00863.

25) Schubert MM, Desbrow B, Sabapathy S, Leveritt M. Acute exercise and subsequent energy intake. A meta-analysis. Appetite 63: 92-104, 2013. doi: 10.1016/ j.appet.2012.12.010.

26) Deighton K, Stensel DJ. Creating an acute energy deficit without stimulating compensatory increases in appetite: is there an optimal exercise protocol? Proc Nutr Soc 73: 352-358, 2014. doi: 10.1017/ S002966511400007X.

27) Mountjoy M, Sundgot-Borgen J, Burke L, Carter S, Constantini N, Lebrun C, Meyer N, Sherman R, Steffen K, Budgett R, Ljungqvist A. The IOC consensus statement: beyond the female athlete triad - relative energy deficiency in sport (RED-S). Br J Sports Med 48: 491-497, 2014. doi: 10.1136/bjsports-2014-093502.

28) Thomas DT, Erdman KA, Burke LM. Position of the Academy of Nutrition and Dietetics, Dietitians of Canada, and the American College of Sports Medicine: Nutrition and Athletic Performance. J Acad Nutr Diet 116: 501-528, 2016. doi: 10.1016/j.jand.2015.12.006.

29) Crabtree DR, Chambers ES, Hardwick RM, Blannin AK. The effects of high-intensity exercise on neural responses to images of food. Am J Clin Nutr 99: 258267, 2014. doi: 10.3945/ajcn.113.071381.

30) Tremblay A, Alméras N, Boer J, Kranenbarg EK, Després JP. Diet composition and postexercise energy balance. Am J Clin Nutr 59: 975-979, 1994. doi: 10.1093/ajen/59.5.975.

31) Kumahara $H$, Ishii $K$, Tanaka $H$. Physical activity monitoring for health management: practical techniques and methodological issues. Int J Sport Health Sci 4: 380-393, 2006. doi: 10.5432/ijshs.4.380.

32) Cornier MA, Melanson EL, Salzberg AK, Bechtell JL, Tregellas JR. The effects of exercise on the neuronal response to food cues. Physiol Behav 105: 1028-1034, 2012. doi: 10.1016/j.physbeh.2011.11.023.

33) Blundell JE, Gibbons C, Caudwell P, Finlayson G, Hopkins M. Appetite control and energy balance: impact of exercise. Obes Rev 16: 67-76, 2015. doi: 10.1111/ obr.12257.

34) Capling L, Beck KL, Gifford JA, Slater G, Flood VM, O'Connor H. Validity of dietary assessment in athletes: A systematic review. Nutrients 9: E1313, 2017. doi: 10.3390/nu9121313.

35) Birkenhead KL, Slater G. A review of factors influencing athletes' food choices. Sports Med 45: 1511-1522, 2015. doi: 10.1007/s40279-015-0372-1.

36）厚生労働省. 日本人の食事攝取基準（2015年版）策定検 討会報告書, 第一出版, 東京, 45-47, 2014. 